\title{
Abnormal glucose transport and GLUT1 cell-surface content in fibroblasts and skeletal muscle from NIDDM and obese subjects
}

\author{
C. M iele ${ }^{1}$, P. Formisano ${ }^{1}$, G . C ondorelli ${ }^{1}$, M. C aruso ${ }^{1}$, F. O riente $^{1}$, F. A ndreozzi ${ }^{1}$, C. G. Tocchetti ${ }^{1}$, G . R iccardi ${ }^{2}$, \\ F. B eguinot ${ }^{1}$ \\ ${ }^{1}$ Department of Cellular and Molecular Biology and Pathology, and C.N. R. Center of Experimental Endocrinology and \\ Oncology, Naples, Italy \\ ${ }^{2}$ Department of Clinical and Experimental Medicine, "Federico II" University of Naples, Naples, Italy
}

Summary Glucose transport and GLUT1 expression were studied in fibroblasts from 7 lean and 5 obese non-insulin-dependent diabetic (NIDDM) subjects with at least 2 NIDDM first-degree relatives and from 12 lean and 5 obese non-diabetic subjects with no family history of diabetes. The obese individuals also had a strong family history of obesity. Fibroblasts from all of the subjects exhibited no difference in insulin receptor binding, autophosphorylation, and kinase and hexokinase activity. At variance, basal 2-deoxyglucose (2-DG) uptake and ${ }^{3} \mathrm{H}$-cytochalasin $\mathrm{B}$ binding were $50 \%$ increased in cells from individuals with NIDDM $(p<0.001)$ and/or obesity $(p<0.01)$ as compared to the lean non-diabetic subjects. Insulindependent (maximally stimulated - basal) 2-DG uptake and cytochalasin B binding were decreased three-fold in cells from the diabetic and/or obese subjects $(p<0.01)$. GLUT1 mRNA and total protein levels were comparable in fibroblasts from all the groups. However, basal GLUT1 cell-surface content was $50 \%$ greater in fibroblasts from the NIDDM and/or obese subjects as compared to the lean non- diabetic individuals while insulin-dependent GLUT1 recruitment at the cell surface was diminished threefold. Increased basal GLUT1 content in the plasma membrane was also observed in skeletal muscle of 4 NIDDM and 3 non-diabetic obese individuals ( $p<0.05$ vs the lean non diabetic subjects). Basal 2DG uptake in fibroblasts from diabetic/obese individuals and lean control subjects strongly correlated with the in vivo fasting plasma insulin concentration of the donor. A negative correlation was demonstrated between the magnitude of insulin-dependent glucose uptake by the fibroblasts and plasma insulin levels in vivo. We conclude that a primary abnormality in glucose transport and GLUT1 cell-surface content is present in fibroblasts from NIDDM and obese individuals. The abnormal GLUT1 content is also present in skeletal muscle plasma membranes from NIDDM and obese individuals. [Diabetologia (1997) 40: 421-429]

Keywords NIDDM, obesity, fibroblasts, glucose, glucose transporter, metabolism.
Received: 9 August 1996 and in final revised form: 11 December 1996

Corresponding author: F. Beguinot, M.D., Ph.D., Dipartimento di Biologia e Patologia Cellulare e Molecolare, Facoltà di Medicina, Università di Napoli "Federico II", Via Sergio Pansini, 5, I-80131 Naples, Italy

A bbreviations: BMI, Body mass index; EDTA, ethylenediaminetetraacetic acid; HEPES, N-2-hydroxyethylpiperazine$\mathrm{N}^{\prime}$-2ethanesulfonic acid; mAb, monoclonal antibody; PAGE, polyacrylamide gel electrophoresis; PMSF, phenylmethylsulfonyl fluoride; TRIS, tris(hydroxymethyl)aminomethane; NIDDM, non-insulin-dependent diabetes mellitus; DMEM, Dulbecco's modified minimum essential medium; 2-DG, 2-deoxyglucose; MEM, minimal essential medium; TBS, tris buffered saline; PBS, phosphate buffered saline.
Genetic factors contribute to insulin-resistance in non-insulin-dependent diabetes mellitus (NIDDM) and obesity [1-7]. These influences might involve either the process of insulin signal transmission across the plasma membrane and/or the biochemical pathways allowing glucose uptake and metabolism by the cells [8]. In fact, genetic defects have been identified in these processes which lead to insulin-resistance both in rare syndromes and in more common forms of NIDDM [8-11]. All of these altered genes appear individually rare and, in most cases, several of them have to be simultaneously expressed for determining overt disease [8]. Whether the function of these 
Table 1. Clinical data of NIDDM and control subjects

\begin{tabular}{|c|c|c|c|c|}
\hline & \multicolumn{2}{|c|}{ Non-diabetic subjects } & \multicolumn{2}{|c|}{ NIDDM subjects } \\
\hline & $\begin{array}{l}\text { Lean } \\
(n=12)\end{array}$ & $\begin{array}{l}\text { Obese } \\
(n=5)\end{array}$ & $\begin{array}{l}\text { Lean } \\
(n=7)\end{array}$ & $\begin{array}{l}\text { Obese } \\
(n=5)\end{array}$ \\
\hline Age (years) & $47(34-66)$ & $49(32-65)$ & $51(32-64)$ & $52(34-62)$ \\
\hline BMI $\left(\mathrm{kg} / \mathrm{m}^{2}\right)$ & $21.6 \pm 2.5$ & $39 \pm 2.4^{\mathrm{a}}$ & $22.1 \pm 2.5$ & $38.4 \pm 2.6^{\mathrm{a}}$ \\
\hline $\mathrm{HbA}_{1 \mathrm{c}}(\%)$ & $5.8 \pm 0.2$ & $6.0 \pm 0.3$ & $7.9 \pm 0.3^{\mathrm{a}}$ & $8.1 \pm 0.1^{\mathrm{a}}$ \\
\hline Fasting plasma glucose $(\mathrm{mmol} / \mathrm{l})$ & $5.2 \pm 0.3$ & $5.3 \pm 0.2$ & $10.2 \pm 1.2^{\mathrm{a}}$ & $10.5 \pm 1.0^{\mathrm{a}}$ \\
\hline
\end{tabular}

Data represent the mean values and dispersion is presented either as range (age) or as \pm SD. ${ }^{a} p<0.001 ;{ }^{b} p<0.01$ vs lean non-diabetic patients

abnormal genes converges and directly determines molecular alterations commonly found in the insulin resistance of NIDDM and obesity is unclear.

GLUT1 is believed to be normally responsible for non-insulin-dependent glucose transport in cells [12, 13] although there is also evidence indicating that its cell-surface content or function may influence the activity of the major insulin-responsive GLUT4 transporter in insulin target tissues [13, 14]. Non-insulindependent glucose uptake appears to be depressed in isolated adipocytes $[15,16]$ but not in skeletal muscle preparations from NIDDM individuals [17]. Abnormalities in GLUT1 mRNA and total cell protein levels have not been detected in muscle [18] or in fat cells [19] from NIDDM individuals, and primary alterations in glucose transport in NIDDM could not be demonstrated in cultured fibroblasts which largely express GLUT1 as a glucose transporter [20, 21]. In all of these studies, however, potential gene dose effects [22] were not taken into account since no selection was undertaken for subjects with a family history of NIDDM. In addition, the analysis of glucose transport in fibroblasts was performed under culture conditions resulting in marked GLUT1 upregulation $[20,21,23]$. Evidence is also available that, in vivo, non-insulin-dependent glucose uptake is abnormally elevated in forearm muscles of NIDDM subjects as compared to non-diabetic individuals at the same blood glucose levels [24]. Finally, in muscle from animal models of obesity and insulin-resistance, elevated GLUT1 levels have been demonstrated at the cell surface [25]. Thus, the function of GLUT1 in NIDDM needs further investigation.

In the present work, this issue has been addressed using cultured skin fibroblasts from NIDDM and obese individuals with at least two first-degree relatives affected.

\section{Materials and methods}

M aterials. Dulbecco's modified minimum essential medium (DMEM) was purchased from GIBCO (Grand Island, N. Y., USA). Gel electrophoresis, dot blot and Western blot reagents were from Bio-Rad (Richmond, Calif., USA), and radioactive materials from Amersham (Arlinghton Heights, Ill., USA). The GLUT1 probe was generously provided by Dr. G. I. Bell, Howard Hughes Medical Institute, The University of Chicago, Ill., USA. Sulfo-NHS-LC-Biotin was from Pierce (Rockford, Ill., USA), GLUT1 mAb from Biogenesis (Sandown, N.H., USA), receptor mAb-3 from Oncogene Science (Manhasset, N. Y., USA), as was $\alpha_{1} \mathrm{Na}^{+} / \mathrm{K}^{+}$ATPase. All other chemicals were from Sigma (St. Louis, MO, U.S. A.).

Subject selection, fibroblast cultures, and skeletal muscle sampling. Patients were selected from the clinic after being diagnosed with NIDDM (according to NDDG criteria [26]) for over 2 years and for having at least 2 first-degree relatives with NIDDM. All of them were over 30 years and had not been treated with insulin during the first 2 years after diagnosis. Similar to the diabetic patients, 4 out of 5 obese NIDDM patients and all of the obese patients with normal glucose tolerance had at least 2 obese first-degree relatives. The remaining obese NIDDM subject had one grossly obese parent (body mass index $>40$ ). Non-diabetic subjects had no glucose intolerance [26] or family history of diabetes and/or obesity. Informed consent was obtained from all of the subjects. Clinical data of the lean and obese subgroups are reported in Table 1. Shoulder skin fibroblasts were obtained by punch biopsy and cultures established as previously described [27]. The cells were grown at $37^{\circ} \mathrm{C}$ in DMEM supplemented with $10 \%$ fetal calf serum in a $5 \% \mathrm{CO}_{2}-95 \%$ air humidified atmosphere. Cultures were used for experimental procedures between the $8^{\text {th }}$ and $15^{\text {th }}$ passage, and, for each individual experiment, the cells were maintained in culture for an equal number of generations before being used since glucose consumption and transport progressively declines at increasing fibroblast passage number. All of the muscle specimens $(\sim 1.5 \mathrm{~g}$ each) used in the present study were obtained from anaesthetized patients (general anaesthesia) undergoing abdominal or orthopedic surgery. All of the patients were starved for $16 \mathrm{~h}$ and were receiving glucose infusion at the time of biopsy. The specimens were from 5 of the lean non-diabetic fibroblast donors ( 2 from vastus lateralis, and 3 from rectus abdominis), from 4 of the lean NIDDM donors (3 from rectus abdominis, and 1 from vastus lateralis), and from 3 obese nondiabetic donors (from vastus lateralis). Immediately after biopsy, the tissue was rinsed and dissected free of 
erythrocytes and connective tissue, and then frozen at $-80^{\circ} \mathrm{C}$ until used.

B inding assays, insulin receptor phosphorylation and kinase activity. ${ }^{125}$ I-insulin binding, insulin receptor phosphorylation and kinase activity were determined as reported previously [28]. For ${ }^{3} \mathrm{H}$-cytochalasin $\mathrm{B}$ binding experiments, fibroblast plasma membranes were first obtained as detailed previously [28], and assessing the reproducibility of the fractionation procedure as described [28]. D-glucose-inhibitable ${ }^{3} \mathrm{H}$-cytochalasin $\mathrm{B}$ binding to plasma membranes was then determined in the presence or the absence of cytochalasin E and analysed as described previously [28].

D etermination of 2-D G and AIB uptake and hexokinase activity. The uptake of 2-deoxy-D-glucose (2-DG) was measured as reported previously [28]. Briefly, confluent cells were incubated with minimal essential medium (MEM) supplemented with $0.5 \%$ albumin for $18 \mathrm{~h}$ at $37^{\circ} \mathrm{C}$ in a $5 \% \mathrm{CO}_{2}$ atmosphere. The medium was aspirated and the cells further incubated for $1 \mathrm{~h}$ with glucose-free MEM containing $0.5 \%$ albumin. More prolonged glucose starvation as described $[20,21]$ minimized the differences in basal glucose transport between the NIDDM/obese and lean control individuals described in the present paper. Cytochalasin B $(50 \mu \mathrm{mol} / \mathrm{l})$ was used to estimate carrier-independent uptake. ${ }^{14} \mathrm{C}-\alpha$ aminoisobutyric acid (AIB) uptake was determined as previously reported [28]. Hexokinase activity in fibroblast homogenates was determined as described previously [29].

D etermination of GLUT 1 mRNA and total cell protein levels. Total cellular RNA was prepared as described previously [30]. For dot-blot analysis, $12.5 \mu \mathrm{g}$ RNA was denatured in $10 \mathrm{mmol} / \mathrm{l}$ $\mathrm{NaOH}, 1 \mathrm{mmol} / \mathrm{l} \mathrm{EDTA}^{2}$, and applied to a Zeta-Probe GT blotting membrane (Amersham-Arlington Heights, Ill, U.S. A.). The filters were baked for $1 \mathrm{~h}$ at $80^{\circ} \mathrm{C}$ and hybridized overnight at $65^{\circ} \mathrm{C}$ in $0.25 \mathrm{~mol} / 1 \mathrm{NA}_{2} \mathrm{HPO}_{4} \mathrm{pH} 7.2,7 \%$ SDS. Filters were then washed in $20 \mathrm{mmol} / 1 \mathrm{Na}_{2} \mathrm{HPO}_{4}, 1 \%$ SDS and autoradiographed on Kodak X-Omat XAR-5 films. The intensity of the spots was quantitated by densitometry using a Howtek Scanmaster 3 instrument (Howtek, Inc., NH, U.S.A.). For quantitation of total cellular GLUT1 protein, cell monolayers were solubilized in $50 \mathrm{mmol} / \mathrm{l}$ HEPES, $\mathrm{pH}$ 7.4, $10 \mathrm{mmol} / 1 \mathrm{Na}_{4} \mathrm{P}_{2} \mathrm{O}_{7}, 100 \mathrm{mmol} / \mathrm{l} \mathrm{NaF}, 4 \mathrm{mmol} / \mathrm{l}$ EDTA, $2 \mathrm{mmol} / \mathrm{l}$ phenylmethylsulfonyl fluoride (PMSF), $0.2 \mathrm{mg} / \mathrm{ml}$ aprotinin, $1 \%$ Triton X-100 (buffer A). Lysate protein $(100 \mu \mathrm{g})$ was separated by $10 \%$ PAGE and transferred to Trans-Blot nitrocellulose membranes by electroblotting (transfer buffer $25 \mathrm{mmol} / \mathrm{l}$ Tris, $192 \mathrm{mmol} / \mathrm{l}$ glycine, $20 \%$ methanol). Nitrocellulose sheets were incubated with tris-buffered saline (TBS) (20 mmol/l TRIS, $137 \mathrm{mmol} / \mathrm{l} \mathrm{NaCl}, \mathrm{pH} 7.6) / 10 \%$ nonfat dry milk, $0.1 \%$ Tween 20 for $2 \mathrm{~h}$ and blotted proteins probed with $1 \mu \mathrm{g} / \mathrm{ml}$ GLUT1 $\mathrm{mAb}$ for $16 \mathrm{~h}$ at $4{ }^{\circ} \mathrm{C}$. Filters were further incubated with TBS buffer containing $0.05 \%$ Nonidet $\mathrm{P}-40$ and $1 \mu \mathrm{Ci} / \mathrm{ml}{ }^{125} \mathrm{I}$-protein A. GLUT1 was finally identified by autoradiography of dried filters and quantitated by densitometry.

D etection of cell-surface and low-density microsome GL UT1 transporters. Confluent fibroblast monolayers were incubated for $45 \mathrm{~min}$ at room temperature in serum-free DMEM supplemented with $0.25 \%$ bovine serum albumin and $100 \mathrm{nmol} / \mathrm{l}$ insulin. Cells were then washed three times with ice-cold phosphate buffered saline (PBS) containing $0.1 \mathrm{mmol} / \mathrm{C} \mathrm{CaCl}_{2}$ and $1 \mathrm{mmol} / \mathrm{l} \mathrm{MgCl}_{2}(\mathrm{Ca} / \mathrm{Mg} \mathrm{PBS})$, and cell-surface proteins biotinylated by incubating for $30 \mathrm{~min}$ at $4{ }^{\circ} \mathrm{C}$ with $0.5 \mathrm{mg} / \mathrm{ml} \mathrm{N}$-hydroxysuccinimide long chain biotin (NHS-LC-biotin) in Ca/
Mg PBS. The biotinylation reaction was quenched as described previously [31] and cells solubilized in $2.0 \mathrm{ml}$ of buffer A. Glucose transporters were then immunoprecipitated with GLUT1 $\mathrm{mAb}(5 \mu \mathrm{g} / \mathrm{ml})$ and separated by electrophoresis on $10 \%$ SDS gels. Proteins were transferred to Trans Blot nitrocellulose membranes by electroblotting at $180 \mathrm{~mA}$ for $1 \mathrm{~h}$ (transfer buffer as described above). Filters were soaked in PBS-T (PBS, $0.1 \%$ tween 20 ) containing $10 \%$ non-fat dry milk for $2 \mathrm{~h}$ at room temperature, rinsed in PBS-T, and further incubated for $1 \mathrm{~h}$ in the same buffer containing horseradish peroxidase-linked streptavidin (Amersham) at 1:1500 dilution. Filters were washed in PBS-T and enhanced chemioluminescence detection was performed according to the manufacturer's protocol (ECL Western Blotting Detection Reagents, Amersham). For detection of intracellular GLUT1 transporters in fibroblasts, low-density microsomal subfractions were isolated as reported previously [32]. Microsomal proteins were separated by electrophoresis on $10 \%$ SDS gels and then blotted as described above. Transporters were probed with GLUT1 mAb followed by ${ }^{125}$ I-protein A detection and densitometric quantitation.

For studies in muscle, purified plasma membranes were first prepared by sucrose gradient separation as described previously [33]. Relative to the crude membrane fractions, the plasma membranes were almost five-fold enriched in 5 '-nucleotidase activity and $\mathrm{Na}^{+} / \mathrm{K}^{+}$ATP ase content. Plasma membrane proteins were separated by SDS-PAGE and blotted as previously described [33]. Detection of glucose transporters was made using GLUT1 $\mathrm{mAb}$ followed by reaction with ${ }^{125} \mathrm{I}$ protein $\mathrm{A}$, autoradiography and quantitation by laser densitometry.

\section{Results}

Primary cultures of skin fibroblasts from 12 unrelated NIDDM subjects and 17 non-diabetic (control) individuals were obtained. Their clinical characteristics are shown in Table 1. The NIDDM individuals were selected for having at least one parent and one additional first-degree relative affected. Obese as well as NIDDM subjects had fasting hyperinsulinaemia indicating insulin resistance.

We have studied glucose transport in fibroblasts from these individuals by measuring the initial rate of 2-deoxyglucose (2-DG) uptake both in the absence and in the presence of insulin. To this end, the cells were used upon an identical number of generations in culture and, at variance with previous studies [20, $21,23]$, with no prolonged glucose deprivation. Results were analysed by subgrouping lean and obese subjects from the NIDDM and the control groups (Fig.1). In the absence of insulin, fibroblasts from lean non-diabetic individuals exhibited an average 2-DG uptake of $0.77 \pm 0.06 \mathrm{nmol} \cdot \mathrm{min}^{-1} \cdot \mathrm{mg}^{-1}$ (mean \pm SD). Lean NIDDM subjects featured an average uptake of $1.15 \pm 0.18 \mathrm{nmol} \cdot \mathrm{min}^{-1} \cdot \mathrm{mg}^{-1}$ (almost $50 \%$ higher; difference with the lean control subjects significant at the $p<0.001$ level by unpaired t-test). A $45 \%$ increased basal 2-DG uptake was also shown in cells from the obese NIDDM as well as the obese non-diabetic subjects (difference with lean 


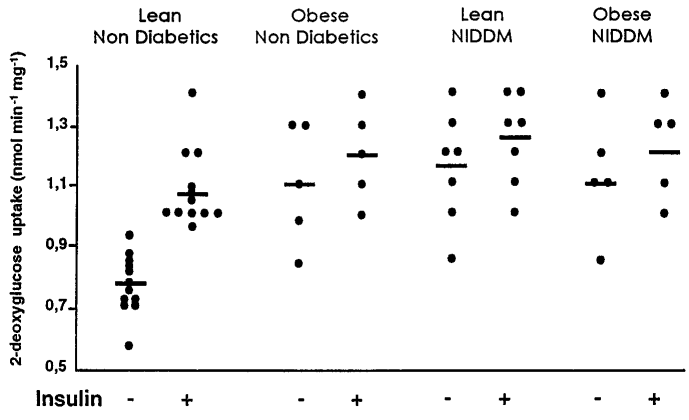

Fig. 1. 2-DG uptake in fibroblasts from NIDDM and non-diabetic individuals. Confluent monolayers of cells from lean non-diabetic $(n=12)$, obese non-diabetic $(n=5)$, lean $\operatorname{NIDDM}(n=7)$, and obese NIDDM individuals $(n=5)$ were incubated in the absence or the presence of $100 \mathrm{nmol} / \mathrm{l}$ insulin for $45 \mathrm{~min}$ as indicated. The initial rate of 2-DG uptake was then measured as described in Materials and methods. Each data point represents the mean of at least three independent determinations in cells from an individual subject. The horizontal bars represent the means of the data point values in each subgroup of individuals

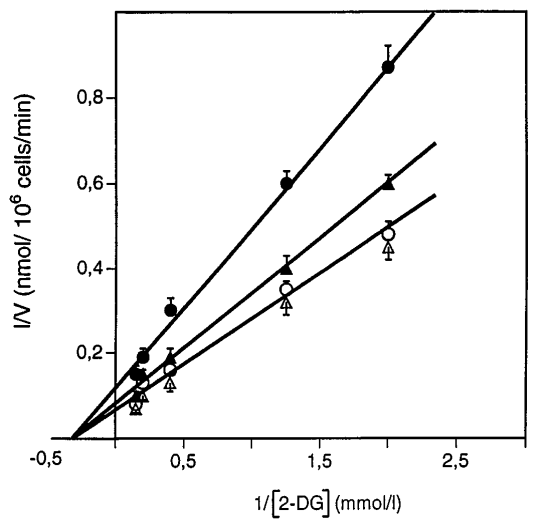

Fig. 2. Lineweaver-Burk analysis of 2-DG transport in fibroblasts from lean NIDDM and lean non-diabetic individuals. Confluent monolayers of cells from the NIDDM $(n=7)$ and non-diabetic individuals $(n=12)$ were incubated in the absence or the presence of insulin as in Figure 1. The uptake was then measured at the indicated concentrations of 2-DG as described under Materials and methods. Data point represent the mean of the values \pm SD obtained in cells from the diabetic (triangles) and control individuals (circles), in the absence (full symbols), or the presence (empty symbols) of insulin. For each individual, at least two independent determinations were performed

control subject significant at the $p<0.01$ level by unpaired t-test). In fibroblasts from all of these individuals, insulin induced an increase in 2-DG uptake which was statistically significant. This was $40 \%$ above the basal in the lean control cells but only about $10 \%$ in cells from the other groups of individuals (difference in the magnitude of insulin response in these latter groups and the lean control subjects significant at $\mathrm{p}<0.01$ by unpaired t-test). However, the average levels (absolute) of maximally insulin-stimulated uptake were not statistically different in any of the cell groups. While similar results were obtained using 3-0-methylglucose rather than 2-DG, basal and insulin-stimulated $\alpha$-aminoisobutyric acid uptake did not show any difference in either the diabetic or the obese individuals when compared to those with normal glucose tolerance (not shown).

Lineweaver-Burk analysis showed that the increased basal 2-DG uptake by fibroblasts from the lean NIDDM individuals as compared to the lean non-diabetic subjects was accompanied by an increase in the $\mathrm{V}_{\max }$ from $7.50 \pm 0.90$ (mean $\pm \mathrm{SD}$; lean control subjects) to $9.8 \pm 1.00 \mathrm{nmol} \cdot \mathrm{min}^{-1} \cdot 10^{-6}$ cells (lean diabetic subjects; Fig.2). No difference was detected in the apparent $\mathrm{K}_{\mathrm{M}}$ values. Exposure of the cells to $1 \times 10^{-7} \mathrm{~mol} / 1$ insulin increased $V_{\max }$ by $4 \mathrm{nmol}$. $\min ^{-1} \cdot 10^{-6}$ cells in the case of lean control fibroblasts and by only $1.3 \mathrm{nmol} \cdot \mathrm{min}^{-1} \cdot 10^{-6}$ cells in the NIDDM fibroblasts. Similarly as with cells from the lean diabetic patients, the increased levels of basal 2DG uptake and the decreased insulin stimulation noted in the obese patients (both in those with NIDDM and those with normal glucose tolerance) as compared to the lean non-diabetic individuals were accompanied by changes in the $\mathrm{V}_{\max }$ for the transport with no variation in the $K_{M}$ (not shown).

To further address the mechanisms responsible for altered glucose uptake in obese and NIDDM fibroblasts, we first studied the insulin receptor function since its activity is an important variable affecting glucose transport in cells. As shown in Table 2, however, there was no significant difference in receptor binding, autophosphorylation and kinase activities between the different groups of individuals. Hexokinase activity was also measured in fibroblast extracts since phosphorylation is the only metabolic step involving 2-DG once it enters into the cells. However, as with receptor functions, we found no difference in the NIDDM and the obese subjects compared with control individuals (Table 2). Therefore, the differences in 2-DG uptake measured in fibroblasts from NIDDM and obese subjects were not attributable to variable cell aging, different receptor function or intracellular glucose phosphorylation.

Next, we estimated the amount of glucose transporters at the cell surface by analysing cytochalasin $\mathrm{B}$ binding to fibroblast plasma membrane preparations. As shown in Figure 3, plasma membrane preparations were obtained from both insulin-exposed and basal cells. Basal membranes from the lean control and NIDDM cells bound $5.40 \pm 0.60$ (mean \pm SD) and $7.60 \pm 1.20 \mathrm{pmol}$ cytochalasin/mg protein $(41 \%$ difference, significant at the $p<0.01$ level by unpaired t-test). Cytochalasin B binding to basal membranes from the obese non-diabetic and the obese NIDDM individuals was $7.30 \pm 1.1$ and $7.50 \pm 1.30$ pmol, respectively (difference with lean control subjects significant at the $p<0.01$ level by unpaired 
Table 2. Insulin receptor functions and hexokinase activity in NIDDM and control individuals

\begin{tabular}{|c|c|c|c|c|}
\hline & \multicolumn{2}{|c|}{ Non-diabetic subjects } & \multicolumn{2}{|c|}{ NIDDM subjects } \\
\hline & Lean & Obese & Lean & Obese \\
\hline $\begin{array}{l}\text { Binding to solubilized receptor } \\
\text { (\% specific binding } / \mathrm{mg} \text { ) }\end{array}$ & $4.0 \pm 0.5$ & $4.1 \pm 0.4$ & $4.2 \pm 0.4$ & $4.0 \pm 0.5$ \\
\hline $\begin{array}{l}\text { Insulin-induced autophosphorylation } \\
\text { (densitometry; \% normal) }\end{array}$ & $98 \pm 1.4$ & $97 \pm 0.8$ & $100 \pm 2.0$ & $102 \pm 1.3$ \\
\hline $\begin{array}{l}\text { Basal kinase activity } \\
\text { (substrate-incorporated }{ }^{32} \mathrm{P} ; \mathrm{dpm} \text { ) }\end{array}$ & $1928 \pm 170$ & $2040 \pm 205$ & $2071 \pm 165$ & $1895 \pm 198$ \\
\hline $\begin{array}{l}\text { Hexokinase activity } \\
\left(\mathrm{nmol} \cdot \mathrm{min}^{-1} \cdot \mathrm{mg}^{-1} \text { protein }\right)\end{array}$ & $11.2 \pm 1.0$ & $10.9 \pm 0.7$ & $11.5 \pm 1.0$ & $11.0 \pm 1.0$ \\
\hline
\end{tabular}

The data represent the mean \pm SD

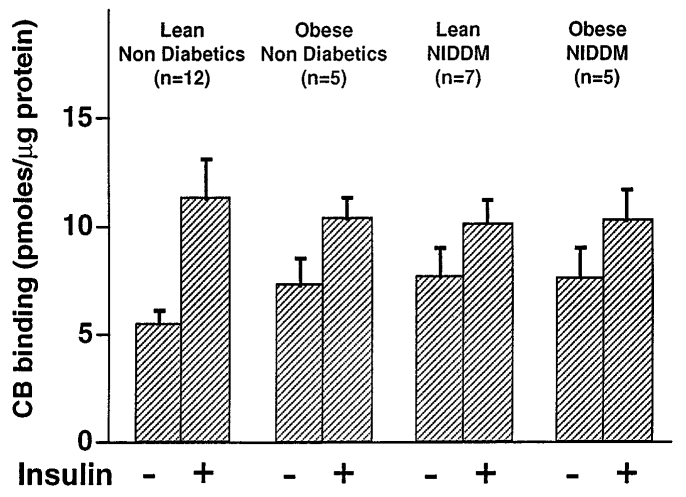

Fig. 3. $\mathrm{CB}$ binding to fibroblast plasma membranes from NIDDM and non-diabetic individuals. Fibroblasts were incubated in the absence or the presence of insulin as in Figure 1. Cells were then harvested for plasma membrane preparation and CB-plasma membrane binding was determined as reported under Materials and methods. Bars represent the mean of the values \pm SD obtained with cells from the diabetic and non-diabetic individuals. For each subject, at least three independent determinations were performed

t-test). Upon insulin stimulation, cytochalasin B binding increased to $11.20 \pm 2.00 \mathrm{pmol}$ in lean control subjects $(110 \%$ increase; variation significant at the $p<0.001$ level). Similar to 2-DG uptake, however, it showed much smaller changes in all of the other groups of membrane preparations $(41,31$ and $40 \%$ increase in those from obese non diabetic individuals, lean NIDDM and obese NIDDM, respectively; $p<0.01$ by unpaired t-test). In each of the four groups of cells, cytochalasin B binding exhibited a significant correlation with 2-DG transport both in the absence and in the presence of insulin (not shown). Since GLUT1 is the major transporter isoform expressed in human fibroblasts, we reasoned that the increased insulin-independent cytochalasin B binding shown in plasma membranes from basal NIDDM and obese cells could depend on alterations of its cellular mRNA levels as well as on different total cellular GLUT1 protein levels. However, quantitation of
GLUT1 mRNA by dot blot analysis revealed no difference in specific RNA levels between lean control, NIDDM, and obese fibroblasts (Fig. 4, top). Similarly, based on Western blot analysis of post-nuclear fractions, there was no significant difference in GLUT1 protein levels between the different groups of cells. We then addressed the hypothesis that GLUT1 content at the cell-surface rather than GLUT1 total content could differ in the NIDDM and the obese subjects as compared to the lean control subjects. To this end, GLUT1 plasma membrane content was compared in NIDDM and control fibroblasts by biotinylating cell membrane proteins in the intact cells followed by cell solubilization and transporter precipitation with GLUT1 mAb and detection with peroxidase-conjugated streptavidin. In cell lysates, these antibodies precipitated a major $45 \mathrm{~K}$ species corresponding to the GLUT1 transporter. Interestingly, under basal conditions, the band was approximately $60 \%$ fainter in plasma membranes from lean control subjects than in those from either the NIDDM or the obese individuals (Fig. 5, top; difference between the lean control subjects and each of the other groups significant at the $p<0.02$ level by unpaired t-test). Consistently, microsomal membranes from basal NIDDM and obese fibroblasts revealed a $44 \%$ reduced GLUT1 content as compared to those from lean non-diabetic individuals $(p<0.01$ by unpaired t-test). Insulin exposure of lean non-diabetic fibroblasts induced an $80 \%$ increase in biotinylated cellsurface GLUT1 $(p<0.001)$ and a similarly sized decrease in microsomal GLUT1. In comparison, in cells from the NIDDM and obese individuals, insulin stimulation increased plasma membrane GLUT1 by only $3-15 \%$, while inducing a correspondingly smaller decrease of that in the low-density microsomes (difference between the lean control subjects and each of the other groups significant at the $p<0.02$ level by unpaired t-test). Purified plasma membranes of skeletal muscle tissue from the obese and NIDDM fibroblast donors also showed a 23 and $31 \%$ 


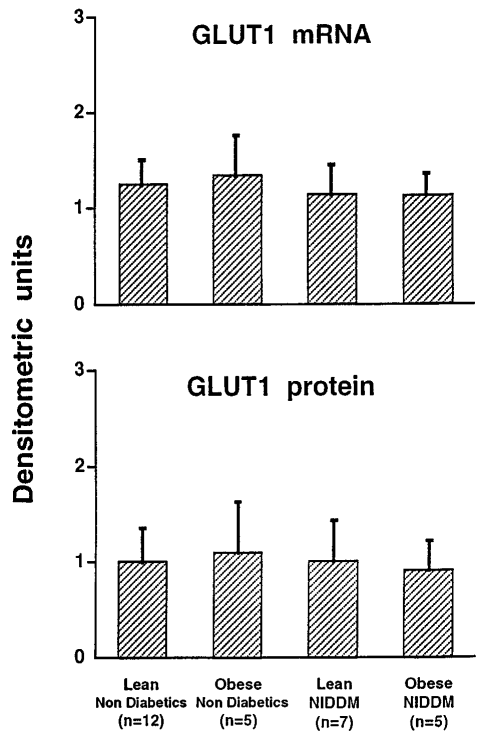

Fig. 4. GLUT1 mRNA and total protein levels in fibroblasts from NIDDM and non-diabetic individuals. GLUT1 mRNA (top) and protein (bottom) levels were determined by dot blot and Western blot analysis, respectively as described under Materials and methods. Quantitation of the labelled spots and bands were performed by densitometry and is reported in the figure as arbitrary units. Bars represent the mean $\pm \mathrm{SD}$ of at least duplicate determinations in each individual subject

increased GLUT1 content compared to lean nondiabetic control subjects (Fig. 6 , top; $p<0.05$ by unpaired t-test). The plasma membrane marker $\mathrm{Na}^{+} /$ $\mathrm{K}^{+}$ATPase did not show any difference between the three groups (Fig. 6, middle). As was the case for the fibroblasts, no significant difference was observed in GLUT1 mRNA content of muscle in the 3 groups of individuals (Fig. 6, bottom).

To further address the significance of the different glucose uptake observed in the NIDDM and the obese subjects, we calculated correlation coefficients for basal and insulin-dependent glucose transport and the following variables: age, sex, body mass index, diabetes duration, fasting plasma insulin, and glucose concentrations, and $\mathrm{HbA}_{1 \mathrm{C}}$. As shown in Figure 7 (top), basal levels of glucose uptake by the fibroblasts significantly correlated with those of in vivo fasting plasma insulin. At variance with the basal, a negative correlation was observed between insulin-mediated glucose uptake in fibroblasts and in vivo fasting plasma insulin levels. Thus, when the lean and obese NIDDM and non-diabetic subjects were analysed together, it appeared that those individuals exhibiting low insulin levels also showed reduced basal glucose uptake and high insulin effectiveness in fibroblasts. Conversely, those individuals which featured high fasting plasma insulin levels also exhibited high levels of basal glucose uptake and small insulin effectiveness. No other variable correlated with either the basal or the insulin-dependent fibroblast glucose uptake.

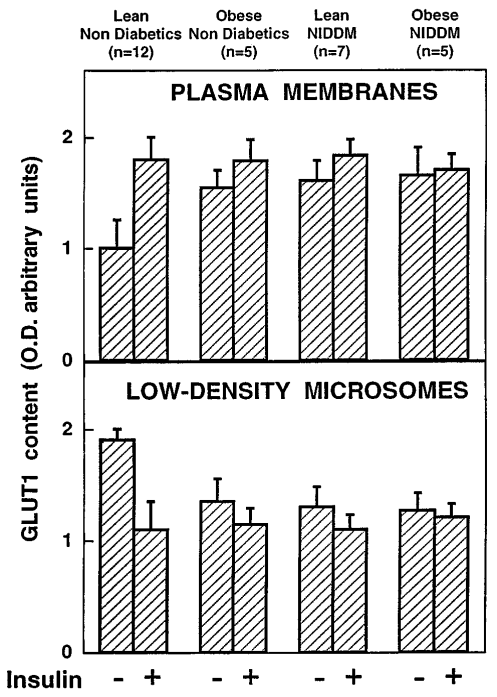

Fig. 5. GLUT1 content of plasma membranes and low-density microsomes in fibroblasts from NIDDM and non-diabetic individuals. Cell-surface GLUT1 transporters were identified upon immunoprecipitation of biotinylated cell protein with GLUT1 mAb followed by detection of blotted transporters with horseradish peroxidase and enhanced chemiluminescence as described under Materials and methods. The identification of intracellular transporters was achieved by blotting and GLUT1 mAb probing microsomal proteins followed by detection with ${ }^{125}$ I-protein A. In both cases, the intensity of the transporter bands was quantified by densitometry and is reported as arbitrary units. Bars represent the mean \pm SD of duplicate determinations in each individual subject

\section{Discussion}

In the present report, we have investigated potential abnormalities in GLUT1 function in NIDDM and obesity. Although not playing any major role in the overall glucose homeostasis, skin fibroblasts represent a convenient system for these studies since: i) they largely express GLUT1 as glucose transporter [34]; and ii) they can be cultured for several generations outside of the donor milieu so that abnormalities in their functional properties can be attributed to genetic rather than environmental factors [35-37]. This distinction cannot be as easily achieved for more legitimate insulin targets such as differentiated muscle tissue and adipocytes, where insulin resistance appears to be significantly contributed by secondary factors [38-40] in addition to the genetic background of the donor [8].

We have shown that, in the basal (i.e. non-insulinstimulated) state, the initial rate of 2-DG uptake is significantly higher in the NIDDM fibroblasts as compared to cells from lean non-diabetic patients. This basal increase corresponded to a decrease in the magnitude of the insulin-stimulated uptake in the diabetic patients. These differences were not due to variable fibroblast aging since all cells were used upon an identical number of generations in 


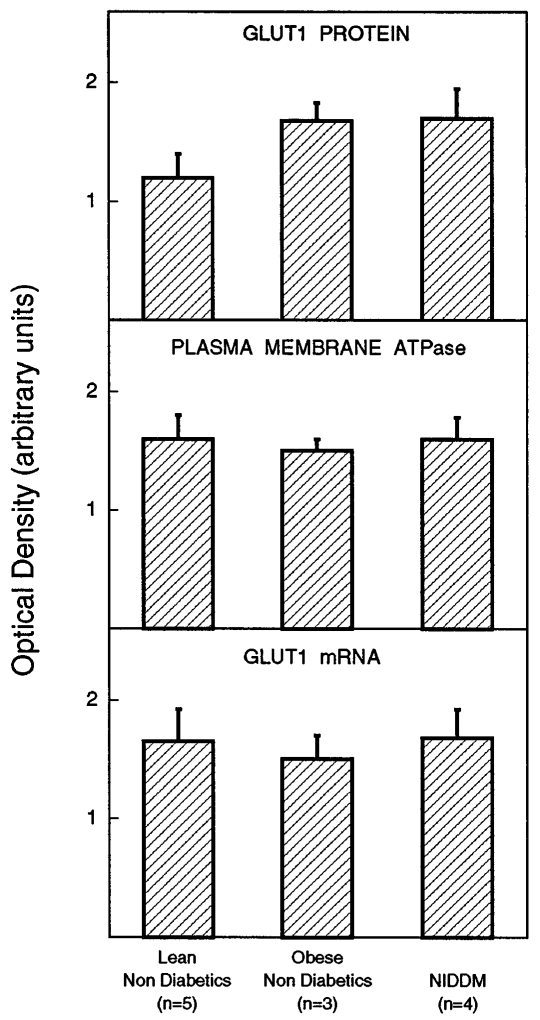

Fig.6. GLUT1 mRNA and GLUT1 protein plasma membrane content in skeletal muscle from NIDDM and non-diabetic individuals. GLUT1 mRNA in surgical specimens of skeletal muscle was determined by dot blot analysis as described in Materials and methods. GLUT1 protein content of purified plasma membrane preparations from the same specimens was determined by Western blot analysis. ATPase content in the plasma membranes was controlled by probing the same filters with $\alpha_{1}-\mathrm{Na}^{+} / \mathrm{K}^{+}$ATPase antibodies. Quantitation of the spots/bands was achieved by densitometry and is reported in the figure as arbitrary units. Bars represent the mean \pm SD of duplicate determinations in each individual subject

culture. In addition, they remained detectable in both low and high passage cells indicating they were not affected by aging itself. Fibroblasts from NIDDM and lean control individuals were almost completely segregated from each other in terms of the basal uptake levels suggesting that the high basal uptake may represent a common defect in this type of diabetes. Previous work on fibroblasts from NIDDM subjects has not reported significant differences in glucose uptake with non-diabetic individuals $[20,21]$. At least in part, this apparent discrepancy is due to technical differences in the assay procedures. In this study, the cells were subjected to a much shorter period of glucose deprivation than in previous studies (see Methods) thus avoiding plasma membrane up-regulation of GLUT1. Under these conditions, we optimized the detection of primary differences in basal 2-DG uptake and cell-surface transporters between control subjects and other
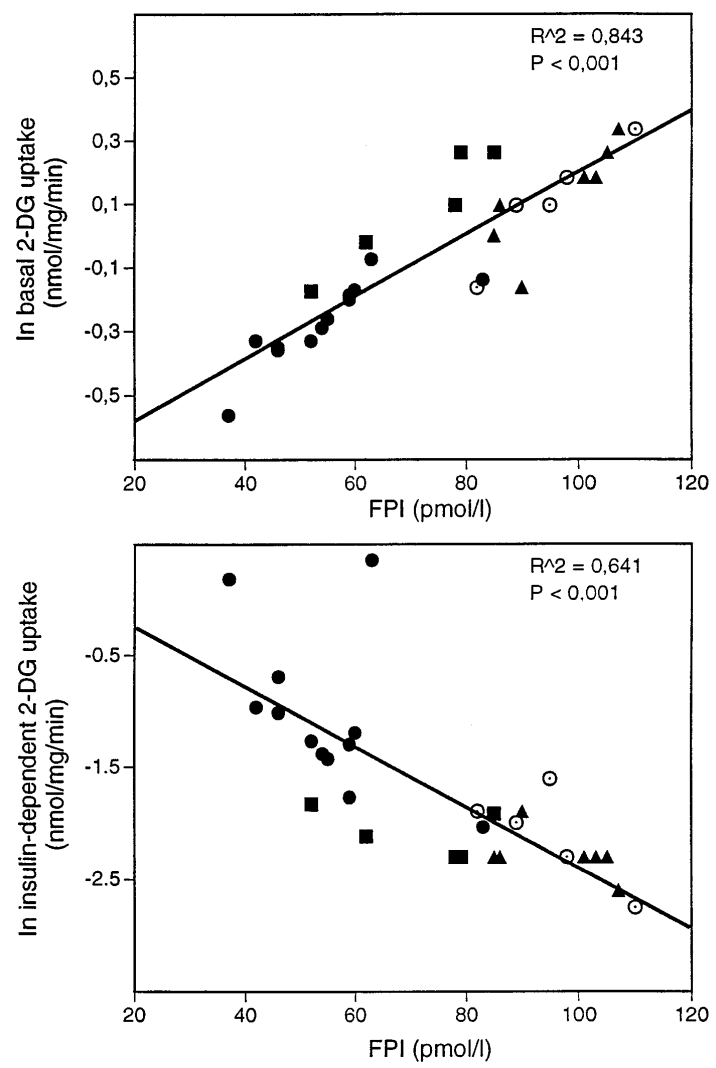

Fig. 7. Correlation between $2-\mathrm{DG}$ uptake by fibroblasts and fasting plasma insulin of the donors. Correlation coefficients were calculated between basal (top panel) or insulin-dependent (bottom panel) uptake and insulin levels in lean NIDDM $(\boldsymbol{\Delta})$, obese NIDDM $(\odot)$, lean non-diabetic $(\mathcal{O})$ and obese non-diabetic individuals $(\square)$. Regression lines were computer generated

groups of individuals (data not shown). In addition, in the present study, the NIDDM individuals were selected for their strong family history of diabetes. This may have determined the selection of subjects with a stronger genetic background than in previous works, contributing to their group segregation. Consistent with this, abnormalities in insulin action have not been found in previous work on fibroblasts from unselected NIDDM individuals [20, 21, 23, 36, 41] while recently in NIDDM fibroblasts, selected as in the present study, Wells et al. [35] reported a genetically determined abnormality in the activation of glycogen synthesis. In NIDDM, no single genetic locus has been shown to be as prevalent as the abnormal glucose transport appears to be in the fibroblasts [42]. Also, the GLUT1 gene locus itself shows no linkage with NIDDM [43]. We might have randomly selected a very homogeneous group of individuals sharing the same genetic defect in basal glucose transport. More likely, the genetic determinant(s) of the abnormal glucose transport in fibroblasts are downstream of the NIDDM susceptibility gene(s) and alterations of several discrete 
susceptibility genes may all have the same effect on fibroblast glucose transport.

As in the obese NIDDM patients, obese individuals with normal glucose tolerance and a strong family history of obesity showed increased basal and decreased insulin-stimulated 2-DG uptake suggesting the presence of the same primary abnormality in both NIDDM and simple obesity. As for NIDDM, the development of obesity is also influenced by several genes [44] although the mechanism is unclear. Interestingly, in cells from obese and NIDDM patients, as well as in those from non-diabetic non-obese subjects, basal 2-DG uptake exhibited an highly significant correlation with fasting plasma insulin levels. The magnitude of insulin effect on glucose transport in these cells was also negatively correlated with fasting plasma insulin. Thus, the hyperinsulinaemic individuals exhibited in vitro insulin resistance suggesting they might also exhibit insulin resistance in vivo and in tissues relevant to glucose disposal. Supporting this view, previous works [45] have shown that hyperinsulinaemia is a marker of insulin resistance of glucose disposal in both NIDDM and obesity. We suggest therefore that the abnormalities in fibroblast glucose uptake we report might also represent a marker for insulin resistance in NIDDM and obese individuals.

Previous in vitro studies in adipocytes and muscle preparations showed depressed or unchanged basal glucose uptake in NIDDM and obesity [15-17]. However, other investigators demonstrated that, in vivo, non-insulin-dependent glucose uptake is elevated in forearm muscle from NIDDM individuals as compared to that in control individuals at equal blood glucose levels [24]. These apparently conflicting results are likely to reflect variability in the model systems adopted in the different studies. In this regard, it is important to underline that the increased 2-DG uptake we describe in the present report may not necessarily result in augmented basal glucose uptake in vivo.

The abnormal 2-DG uptake in fibroblasts from NIDDM and obese subjects was accompanied by increased cytochalasin B plasma membrane binding and plasma membrane basal content of the GLUT1 transporter. These changes did not appear to be restricted to fibroblasts since increased plasma membrane content was also observed in skeletal muscle from the same NIDDM and obese individuals. The changes were unlikely to result from a basic defect in insulin signalling since binding as well as kinase activities of the insulin receptor were not different in the fibroblasts from the various groups of subjects. In addition, similar to previous studies [18], GLUT1 total protein and mRNA levels were essentially identical in fibroblasts from control and NIDDM individuals. We suggest therefore that genetic determinant(s) may result in a constitutive plasma membrane recruitment of GLUT1 in fibroblast and skeletal muscle of NIDDM and obese subjects.

Handleberg et al. [25] have recently shown that genetically diabetic and obese Zucker rats exhibit increased GLUT1 cell-surface content in skeletal muscle. This abnormality was only partially reverted after normalization of blood glucose levels suggesting that, at least in part, it was genetically determined in this animal model. In addition, these authors found that, in the same rat muscle membrane preparations, GLUT1 and GLUT4 cell-surface content were inversely correlated. Evidence for reciprocal regulation of GLUT1 and GLUT4 has also been obtained in adipocytes [46, 47], cultured muscle cells [48-50] and skeletal muscles from transgenic animals overexpressing GLUT1 [13]. One might speculate therefore that the augmented GLUT1 plasma membrane content we have shown in fibroblasts and muscle tissue from NIDDM and obese individuals might impair GLUT4 cell-surface translocation or functions and contribute to insulin resistance in these tissues.

A cknowledgements. This work was supported in part by Telethon-Italy (Grant E327), the European Community (Contract BMH4-CT96-0751), the Exchange Program between Italian Scientists and the National Institute of Health funded by the Italian Department of Education (Ministero della Ricerca) and the Italy-France Exchange Program between the Italian Council of Research (C.N.R.) and the Institut National de la Santée et de la Recherche Medicale (I.N.S.E.R.M.) funded by both Institutions.

We are grateful to Drs. E. Consiglio, G. Salvatore and G. Vecchio for continuous support during the course of this work, to Dr. G. Sesti for helpful discussion and to Dr. L. Beguinot and Dr. F. Giorgino for critical reading of the manuscript. We also thank Dr. D. Liguoro for his technical help.

\section{References}

1. Gulli G, Ferrannini E, Stern M, Haffner S, DeFronzo RA (1992) The metabolic profile of NIDDM is fully established in glucose-tolerant offspring of two Mexican-American NIDDM parents. Diabetes 41: 1568-1575

2. Lillioja S, Mott DM, Howard BW et al. (1988) Impaired glucose tolerance as a disorder of insulin action: longitudinal and cross-sectional studies in Pima Indians. N Engl J Med 318: 1217-1225

3. Bogardus C, Lillioja S, Nyomba F et al. (1989) Distribution of in vivo insulin action in Pima Indians as mixture of three normal distributions. Diabetes 38: 1423-1432

4. Martin BD, Warram JH, Krolewski AS, Bergman RN, Soeldner JS, Kahn CR (1992) Role of glucose and insulin-resistance in development of type II diabetes mellitus: results of a 25-year follow-up study. Lancet 340: 925-929

5. Eriksson J, Fransilla-Kallunki A, Ekstrand A, Saloranta C, Widen E, Schalin C, Groop L (1989) Early metabolic defects in persons at increased risk for non-insulin dependent diabetes mellitus. N Engl J Med 321: 337-343

6. Warram JH, Martin BC, Krolewski AS, Soeldner JS, Kahn CR (1990) Slow glucose removal rate and hyperinsulinemia precede the development of type II diabetes in the offspring of diabetes parents. Ann Int Med 113: 909-915

7. Schalin-Jantti C, Harkonen M, Groop LC (1992) Impaired activation of glycogen synthase in people at increased risk of developing NIDDM. Diabetes 41: 598-604 
8. Kahn CR (1994) Insulin action, diabetogenes, and the cause of type II diabetes. Diabetes 43: 1066-1084

9. Taylor S, Wertheimer E, Accili D et al. (1994) Mutations in the insulin receptor gene: update 1994. Endocrine Rev 2: 58-65

10. Cocozza S, Porcellini A, Riccardi G et al. (1992) NIDDM associated with mutation in tyrosine kinase domain of insulin receptor gene. Diabetes 41: 521-526

11. Tao T, Matsutani A, Kaku K (1994) Defects of candidate genes in Japanese NIDDM - glucose transporter gene (GLUT1 gene, GLUT4 gene). Nippon Rinsho 52: 2697-2701

12. Bell GI, Burant CF, Takeda J, Gould GW (1993) Structure and function of mammalian facilitative sugar transporters. J Biol Chem 268: 19161-19164

13. Marshall BA, Ren JM, Johnson DW et al. (1993) Germline manipulation of glucose homeostasis via alteration of glucose transporter levels in skeletal muscle. J Biol Chem 268: 18442-18445

14. Czech MP, Clancy BM, Pessino A, Woon CW Harrison SA (1992) Complex regulation of simple sugar transport in insulin-responsive cells. TIBS 17: 197-201

15. Scarlett JA, Kolterman OG, Ciaraldi TP, Kao M, Olefsky JM (1983) Insulin treatment reverses the postreceptor defect in adipocyte 3-O-methylglucose transport in type II diabetes mellitus. J Clin Endocrinol Metab 56: 1195-1201

16. Garvey WT, Huecksteadt TP, Matthaei S, Olefsky JM (1988) Role of glucose transporters in the cellular insulin resistance of type II non-insulin-dependent diabetes mellitus. J Clin Invest 81: 15281536

17. Dohm GL, Tapscott EB, Pories WJ et al. (1988) An in vitro human muscle preparation suitable for metabolic studies: decreased insulin stimulation of glucose transport in muscle from morbidly obese and diabetic subjects. J Clin Invest 82: 486-494

18. Pedersen O, Bak JF, Andersen PH, Lund S, Moller DE, Flier JS, Kahn B (1990) Evidence against altered expression of GLUT1 or GLUT4 in skeletal muscle of patients with obesity or NIDDM. Diabetes 39: 865-870

19. Garvey WT (1992) Glucose transport and NIDDM. Diabetes Care 15: 396-417

20. Germinario RJ, Oliveira M, Manuel S, Taylor M (1987) Hexose transport regulation in cultured fibroblasts derived from normal and type II diabetic patients. Clin Invest Med 10: 295-302

21. Berhanu P, Tsai P, Olefsky JM (1982) Insulin-stimulated glucose transport in cultured fibroblasts from normal and noninsulin-dependent (type II) diabetic human subjects. J Clin Endocrinol Metab 55: $1226-1230$

22. O'Rahilly S, Wainscoat JS, Turner RC (1988) Type 2 (non-insulindependent) diabetes mellitus: new genetics for old nightmares. Diabetologia 31: 407-414

23. Howard BV, Fields RM, Mott DM, Savage PJ, Nagulsparan M, Bennett PH (1980) Diabetes and cell growth: lack of differences in growth characteristics of fibroblasts from diabetic and non diabetic Pima Indians. Diabetes 29: 119-124

24. Capaldo B, Santoro D, Riccardi G, Perrotti N, Saccà L (1986) Direct evidence for a stimulatory effect of hyperglycemia per se on peripheral glucose disposal in type II diabetes. J Clin Invest 77: 1285-1290

25. Handberg A, Kayser L, Høyer PE, Michelsen J, Vinten J (1994) Elevated GLUT1 level in crude muscle membranes from diabetic Zucker rats despite a normal GLUT1 level in perineurial sheaths. Diabetologia 37: 443-448

26. National Diabetes Data Group (1979) Classification and diagnosis of diabetes mellitus and other categories of glucose intolerance. Diabetes 28: 1039-1057

27. Sly WS, Grubb J (1979) Isolation of fibroblasts from patients. In: Jakoby WB, Pastan IH (eds) Methods in enzymology, Vol. 58. Academic Press, New York, pp 444-450

28. Petruzziello A, Formisano P, Miele C et al. (1993) Defective insulin action in fibroblasts from non-insulin-dependent diabetes mellitus patients with Gln ${ }^{1152}$ insulin receptor mutation. J Clin Endocrinol Metab 77: 409-412

29. Kletzien RF, Perdue J (1974) Sugar transport in chick embryo fibroblasts. J Biol Chem 249: 3366-3374
30. Chomczynski P, Sacchi N (1987) Single step method of RNA isolation by acid-guanidinium thiocyanate phenol chloroform extraction. Anal Biochem 162: 156-159

31. Levy-Toledano R, Caro LHP, Hindman N, Taylor SI (1993) Streptavidin blotting: a sensitive technique to study cell-surface proteins; application to investigate autophosphorylation and endocytosis of biotin-labelled insulin receptors. Endocrinology 133: 1803-1808

32. Clancy BM, Harrison SA, Buxton JM, Czech MP (1991) Protein synthesis inhibitors activate glucose transport without increasing plasma membrane glucose transporters in 3T3-L1 adipocytes. J Biol Chem 266: 10122-10130

33. Klip A, Ramlal T, Cartee GD, Gulve EA, Holloszy J (1990) Recruitment of GLUT4 glucose transporters by insulin in diabetic rat skeletal muscle. Biochem Biophys Res Commun 172: 728-736

34. Longo N, Griffin D, Shuster R, Langley S, Elsas LJ (1989) Increased glucose transport by human fibroblasts with a heritable defect in insulin binding. Metabolism 38: 690-697

35. Wells AM, Sutcliffe IC, Johnson AB, Taylor R (1993) Abnormal activation of glycogen synthesis in fibroblasts from NIDDM subjects. Diabetes 42: 583-589

36. Prince MJ, Tsai P, Olefsky JO (1981) Insulin binding, internalization, and insulin receptor regulation in fibroblasts from type II, non-insulin-dependent diabetic subjects. Diabetes 30: 596-600

37. Magre J, Reynet C, Capeau J, Blivet M-J, Picard J (1988) In vitro studies of insulin resistance in patients with lipoatrophic diabetes: evidence for heterogeneous post-binding defects. Diabetes 37: 421-428

38. Zierath JR, Galuska D, Nolte LA et al. (1994) Effects of glycaemia on glucose transport in isolated skeletal muscle from patients with NIDDM: in vitro reversal of muscular insulin resistance. Diabetologia 37: $270-277$

39. Zierath JR, He L, Gumà A et al. (1996) Insulin action on glucose transport and plasma membrane GLUT4 content in skeletal muscle from patients with NIDDM. Diabetologia 39: 1180-1189

40. Gulve EA, Ren JM, Marshall BA, et al. (1994) Glucose transport in skeletal muscles from transgenic mice overexpressing GLUT1. J Biol Chem 269: 18366-18370

41. Goldstein S, Littlefield JW (1969) Effect of insulin on the conversion of glucose C-14 to C-14- $\mathrm{O}_{2}$ by normal and diabetic fibroblasts in culture. Diabetes 18: 545-549

42. Hanis CL, Boerwinkle E, Chakraborty R, et al. (1996) A genomewide search for human non-insulin-dependent (type2) diabetes genes reveals a major susceptibility locus on chromosome 2 . Nat Genet 13: 161-166

43. Baroni MG, Alcolado JC, Gragnoli C, et al. (1994) Affected sibpair analysis of the GLUT-1 glucose transporter gene locus in noninsulin-dependent diabetes mellitus (NIDDM): evidence for no linkage. Hum Genet 93: 675-680

44. Ravussin E (1995) Metabolic differences and the development of obesity. Metabolism 44: 12-14

45. Olefsky J, Farquhar JW, Reaven G (1973) Relationship between fasting plasma insulin level and resistance to insulin-mediated glucose uptake in normal and diabetic subjects. Diabetes 22: 507-513

46. Hainault I, Guerre-Millo M, Guichard C, Lavau M (1991) Differential regulation of adipose tissue glucose transporters in genetic obesity (fatty rats). J Clin Invest 87: 1127-1131

47. Pedersen O, Kahn CR, Kahn BB (1992) Divergent regulation of the GLUT1 and GLUT4 glucose transporters in isolated adipocytes from Zucker rats. J Clin Invest 89: 1964-1973

48. Mitsumoto Y, Burdett E, Grant A, Klip A (1991) Differential expression of the GLUT1 and GLUT4 glucose transporters during differentiation of L6 muscle cells. Biochem Biophys Res Commun 175: 652-659

49. Koivisto U-M, Martinez-Valdez H, Bilan PJ, Burdett E, Ramlal T, Klip A (1991) Differential regulation of the GLUT1 and GLUT4 glucose transport systems by glucose and insulin in L6 muscle cells in culture. J Biol Chem 266: 2615-2621

50. Bashan N, Burdett E, Hundal HL, Klip A (1992) Regulation of glucose transport and GLUT1 glucose transporter expression by $\mathrm{O}_{2}$ in muscle cells in culture. Am J Physiol 262:C682-C690 